UDC 811.111.659(3)

DOI https://doi.org/10.32838/2663-6069/2020.2-2/24

Kostenko $V$. G.

Ukrainian Medical Stomatological Academy

\title{
TENSE AND ASPECT IN INFORMED CONSENT TEMPLATES FOR DENTAL TREATMENT IN FUNCTIONAL DIMENSION
}

\begin{abstract}
Patient's voluntary informed consent for medical intervention has been known as an integral part of the modern system of moral, ethical and legal regulation of healthcare provision. The purpose of this study is to provide the analysis of the verb tense and aspects in the texts of informed consent templates for dental treatment from functional perspective. Verbs are in the focus of the study because of their semantic, grammar, and syntactic complexity. Verbs appear not only as equally meaningful elements in the sentences as nouns or nominative phrases, but as important constituents of the conceptual map for activities that occur over the reference situation. The dynamism of the studied documents is primarily predetermined by the multiplicity of aspects underlying the communicative situation of engaging patients in the discourse of decision making. The informativeness and communication density of the verbs consists not only in their designating actions, processes, conditions characteristic of the information transfer between the addressers and addressees: verbs can express recurrence of actions, its accomplishment, completeness, continuity, telicity, sequence of events. The results have revealed that the most frequently used grammar verb forms are Present Simple, Present Perfect, and Future Simple, while Present Progressive and Past Simple are marginal. The low percentage of Present Progressive and Past Simple verbs can be explained by the peculiarities of temporal context of the reference situation of health decision making, which is based on resulativeness of past actions, relevant for moment of signing the form, expressed by the Present Perfect, and is mainly oriented towards the future. To achieve pragmatic goals and to avoid creating a minefield of difficulties for patients, the addressors tend to select verb forms, which convey the situation of information transfer and health decision making in the most precise and easy-to-read way. Tense and aspect play an important role in structuring the sentence, act as temporal deictic markers, as indicators of the interpersonal function as they stresses the role of the addressor and addressee in communication, and as text-structuring devices.
\end{abstract}

Key words: informed consent for dental treatment, special discourse, verb, tense, aspect, frequency.

Background. Specialized discourses have become a focus of close researchers' attention worldwide. This is especially relevant for medical and healthcare discourse, as practice in this area is gaining great social, political, and cultural importance, and its clearer understanding can contribute much to providing high-quality care. As Ahmadreza Yazdannik et al claim, "the nature of the knowledge fundamental to health care and the power it wields during its practice, is of continuing interest to philosophers, social scientists and anthropologists, as well as to those individuals who directly use it in administering health care, namely, doctors, nurses, and allied health professionals" [30].

The communication in the field of healthcare is conducted according to organized social actions and textual practices, genres, which, on the one hand, are well established, and, on the one hand, are constantly evolving in order to respond to new communicative demands. There is a voluminous body of literature elucidating the multidimensionality of genres in specialized discourses (V. K. Bhatia, M. A. Halliday, J. C. Sager, J. M Swales. K. Hyland). Professional genres are not merely communicative instruments, according to G. Parodi, "genre knowledge, socially and individually constructed, is stored in the form of cognitive representations and, from this perspective, they will be activated and will materialise in specific texts, within social and cultural contexts, according to the nature of each case" [21]. Genres created in discourse practices in specific settings build up the genre systems, defined by C. Bazerman as "interrelated genres that interact with each other in specific settings" [4, p. 97]. The genre system of medical and healthcare discourse has elaborated the number of genres for different purposes in the large areas of intra-professional, doctor-lay person, and inter-professional communication that reflect discourse community conventions within particular sociocultural context. Although a lot of medical and healthcare genres have been extensively research and described (M. Gotti, P. Ezpeleta-Piorno, D. L. Fryer, 
H. Bowels), the genre of informed consent playing an exceptional role in healthcare settings is somewhat underestimated and reported partially or superficially. There have been a few reports of national and international researchers devoted to their generic peculiarities, rhetoric and linguistic characteristics $[1 ; 2$; $22 ; 29]$. The in-depth linguistic analysis of informed consent forms, which are integral part of the modern system of moral, ethical and legal regulation of healthcare provision, is not only of great applicability in terms to facilitate achieving clear communication through thoroughly selected vocabulary, grammar, formatting, and, thus, to lessen resistance in readers, but it also provides an insight into a complex set of cues that help to decode a particular situation model described in texts of informed consents, as well as to highlight conventions within the socio-cultural context where it is produced.

The purpose of this study is to provide the analysis of the tense and aspect of verbs in the texts of informed consent templates for dental treatment from functional perspective. Verbs are in the focus of the study because of their semantic, grammar, and syntactic complexity.

Materials and methodology. For the purpose of this study, we compiled a corpus of 60 original informed consent templates (ICT) for dental treatment used in the USA healthcare settings authorized to provide oral and dental services (New York City Metropolitan Hospital Center, Alliance for Dental Care PLLC (Rochester, NH)), and those given by medical insurance companies (Dentists Benefits Insurance Company (DBIC), MedPro Group). The templates were searched for using Google search engine and downloaded from internet sources Open Dental Software, American Dental Association dental records reference, Delta Dental Incorporation. This qualitative study was carried out within functional approaches. A general principle of functional approach implies studying the elements of a language, language resources and their correlations in terms of their functions in communication, i.e. how they relate to each other and how they create units of meaning [26].

The methodology of the study included discourse analysis for studying language in relation to its social context ("the analysis of language as it is used to enact activities, perspectives, and identities" $[14$, p. 4]. Discourse analysis is composed of two main dimensions, textual, and contextual. Textual dimensions are those which account for the structure of discourses, while contextual dimensions relate these structural descriptions to various properties of the social, political, or cultural context in which they take place [28]. Among the methodology applied there was the analysis of generic structure to identify and name the main themes in the documents; partof-speech tagging; semantic and syntactic analysis, elements of sociolinguistic analysis. Online programs Text Analyzer (https://www.online-utility.org) and Textalyser (http://textalyser.net/) were used for identifying frequency of word occurrence. The finite verb phrase of each sentence is analyzed in search for tense and aspect.

Results and Discussion. The situation of information exchange between the doctor and patient during the process of obtaining / giving voluntary informed consent can be described in terms of a mutually responsive collaborative dialogic conversation, and the authors of the ICTs attempt to convey the subject matter of the dialogue appropriately for both parties and to reflect key situational aspects first of all through the thorough selection of lexis and grammar. The lexicon is known as the most striking and marked feature of specialized discourses [24, p. 320], however, linguistic resources for expressing epistemic or affective stance include not only the lexicon, but the grammatical and syntactical structures (e.g. choice of pronouns, verb voice, tense, aspect, word order. Researches are beginning to show that grammar categories as like mood, modality, tense, aspect are evidences of speaker's point of view or attitude [25, p 298]. Anyway, numerous reports claim that the lexicon and grammar as well as other knowledge components are mutually dependent and interact in our use of language [17, p. 57].

Though the content area of informed consent templates is highly context-specific and mainly relates to medicine, the lexical layer of the texts studied is represented predominantly by common language vocabulary (72\%) mixed with special and technical vocabulary of professional languages of medicine, dentistry $(21 \%)$ and law (7\%). Semi-technical language was also found, such as 'allergic reactions', 'concomitant drug use', 'nerve exposure' etc., which, while not involving technical terminology is based on assumptions regarding readers' familiarity with particular terms. The identification and quantification of word classes (parts of speech) in the ICTs have shown the following: that nouns make up $32 \%$ of the total number of words both content and functional, verbs used in either a finite or non-finite way constitute $26.8 \%$, and adjectives, which share is $8.7 \%$. The English sentence is typically characterized by a dispersal of verbal elements over various parts of the predicate, such that it is often difficult to assemble verbs and 
verbal phrases from the texts [19, p. 97]. But in this study the focus is on the simple and complex finite verb phrases as well as phrases with modal verbs.

Though nouns and nominal groups are considered as far prevalent in written texts, the share of verbs is used to a much greater extent in the ICTs compared to other written texts of legal and academic discourses. The most frequent verbs according to findings obtained by Text Analyzer and Textalyze online programs, e.g. understand, recommended, advise, consent, cause, prevent are central to the main themes in the texts studied; they serve as text-forming dominants in the organization of the information, its hierarchic representation that is especially relevant for the patients.

Unlike the language of most written texts of legal or academic discourses, for which nominalization and nominal groups are viewed as a universal means for denoting new knowledge, concepts, and ideas, thereby creating more complex expressions and providing higher information density, the language of ICT texts seems as less artificial and more dynamic due to employing more verbs and verbal forms. The dynamism of the documents studied is primarily predetermined by the multiplicity of aspects underlying the communicative situation of engaging patients in "meaningful discourse in an effort to optimize patient understanding of diagnoses and treatments, including their rationale, risks, benefits, goals, and alternative treatment options" [23]. An Informed Consent Form must also document the patient's consent or agreement to take treatment or procedure. Verbs in this context appear as an important constituent of the conceptual map for activities that occur over the reference situation. The informativeness of the verbs consists not only in their designating actions, processes, conditions characteristic of the information transfer between the addressers and addressees: verbs can express recurrence of actions, its accomplishment, completeness, continuity, telicity, sequence of events, therefore the verbs often appear as more meaningful elements in the sentences of the texts studied than nouns or nominative phrases, for example: I agree to return promptly to have my root canal completed. I realize that if I fail to show up, or if I cancel future appointments and do not return, that I am still responsible for the full fee of the procedure [38]. Before I begin treatment, I want to be certain that I have provided you with enough information in a way you can understand [37].

P. J. Hopper claims that "in any utterance a particular importance is universally attached to the temporal contour of a state of action and the speakers' attitude towards it" $[18$, p. 82], whose grammatical correlates are the categories of tense, aspect and modality; G. Leech considers tense and aspect among the linguistic roots of pragmatics [20]. Tense describes the way, in which events, processes and states relate to the time axis. As a_temporal operator, tense applies to the basic form of a sentence, and shifts the evaluated time of that sentence to the past or to the future. D. Crystal postulates that tense is a category used in the grammatical description of verb referring primarily to the way the grammar marks the time at which the action denoted by the verb took place [11, p. 380]. Like tense, aspect is characterized in terms of time, however, in a different way, which covers the perfective-imperfective distinctions [9-10]. It is a morphological device used to convey information about the time course and duration of an activity. The features of aspect include the beginning, termination or progression of a situation. L. J. Brinton defines aspect as a "way conceiving the passage of time" [6, p. 4]. Moreover, the tense system and aspects are an important part of temporal deixis, which denotes the orientation or position of actions and events in time.

Specificity and complexity of the reference situation of providing the patient with information essential for making an educated voluntary decision is represented in the ICTs not only through the selection of the most appropriate vocabulary, but through the proper construction of phrases choosing grammar forms that reflect different types of eventuality and encode temporal information, temporal logic.

Of all the English verb tenses and aspects, there have been found out only five typically used combinations for creating ICTs: Simple Present (39\%), Perfect Present (35\%), Simple Future (23\%), Continuous Present (6\%), Simple Past (3\%).

The most frequent tense is the Simple Present, described as "the most general and unmarked category" [16, p. 29], is highly predictable. Most of the verbs in the Simple Present refer to things in general, or express general facts within the field of dentistry or special scientific facts, for example, when describing the development or progression of diseases, their course, treatment and prevention: The bacteria that cause tooth decay occur in the presence of sugars. Prevention of dental caries improves with proper diet, fluoride therapy, use of dental sealants, and regular dental examinations and cleanings [33]. Root canal therapy is indicated when the pulp chamber of the tooth is contaminated by bacteria causing the canals to become infected [44]. Treatment duration varies depending on the complexity of your doctor's prescription [34]. 
There is a large group of stative (non-continuous) verbs extensively employed in creating ICTs. There have been found out a subgroup of frequently used cognitive verbs signalling the type of mental operations that patients are expected to perform over the comprehension of the facts and circumstances relating to the dental treatment proposed, e.g. to understand, to know, to realize, to acknowledge, to conclude, to infer, to believe, or expressing the opinion or thoughts of doctors, experts. These verbs tent to be Simple Present forms: I understand that depending on my diagnosis, alternatives to extraction may exist which involve other disciplines in dentistry [45]. We understand that dentistry is a stressful and worrying event [38]. $<\ldots>$ and I believe my patient understands what has been explained [40].

Verbs of volition (to wish, to agree, to authorize, to assume, to permit, to reject, to consent, to attest) as an another subtype of cognitive verbs, denoting acts of making a conscious choice or decision, are used in the Present Simple as well: I voluntarily assume any and all known possible risks, including the risk of substantial harm, if any, which may be associated with any phase of this treatment in hopes of obtaining the desired results, which may or may not be achieved [36]. In light of the above, I hereby authorize Dr. to proceed with the root canal therapy [43]. I attest that I have discussed the risks, benefits, consequences, and alternatives of crowns with (patient's name) who has had the opportunity to ask questions [44].

The prevalence of the Simple Present in the texts studied can be driven by the necessity to present a number of facts critical for the decision-making in this context. Moreover, it can be assumed that since verbs in the Present Simple are shorter in the number of syllables, have no tense morphemes (third-person singular morpheme $-\mathrm{s}$ is as an exception), and therefore simpler to be grasped, they are more desirable and grammatically relevant in the ICTs elaborated for an average patient, who is presupposed to have an 8th grade reading level according to International standard classification of education [3], however, most informed consent templates are written at a 10th grade reading level or higher [12, p. 130].

Numerous grammar reports claim that the verbs in the perfect aspect are far less prevalent than verbs in non-pefective aspect; they are still fairly common in all registers $(5 \%$ to $10 \%$ in conversation, fiction, news and academic) [5, p. 461]. Our study demonstrates that Present Perfect is the second commonly used grammar form of the verbs in ICTs. The Present Perfect is a compound verbal form indicating that "the goal of the utterance is not to locate a situation at some definite point in the past, but to offer it as relevant to the current moment" [8, p. 61]. The Present Perfect "signals a significant persistence of results, a continued truth value, a valid present relevance of the effects of earlier events, the continued reliability of conclusions based on earlier behaviour" $[27$, p. 8]. The verbs in the Perfect Tense in the ICTs have been found out approximately as frequent as in the Present Simple. The decision of ICT addressors to operate with the Present Perfect indicates their intention emphasize on the high significance of results derived from a past time situation, which are relevant at the time of signing informed consent: My doctor has carefully examined my mouth. Alternatives to this treatment have been explained. I have tried or considered these methods, but I desire a bone graft to help secure the replaced missing teeth [35]. In terms of pragmatics, all the verbs in the Present Perfect found in the ICTs can be described as resultative non-existential [13, p. 600-602].

The Present Perfect is the most commonly used to confirm that the patient understands the rationale, goals, benefits, and risks of the proposed treatment: My questions have been answered to my satisfaction. I am signing below that I have read and understood this form [44].

Present Perfect verbs in the ICTs respectfully urge the patient to be more involved in the process of making health decision and, thus, to act as a reasonably informed and responsible participant in health decision, forestalling "you're the doctor; you decide" attitude

The Present Perfect verbs impel to causal link between past actions / events (information retrieval and comprehension) and the moment of inform consent signing as well as possible consequences: I have provided complete and accurate medical and personal history, including current medications. I have had all my questions answered regarding this procedure and its potential risks to me [44]. I have also reported any prior allergic or unusual reactions to drugs, food, insect bites, anesthetics, pollens, dust, blood or body diseases [38]. The third commonly used verb grammar form in ICTs is the Future Simple. In English, the Future Simple form (will / shall form) is quite disputable since there are basically four ways of referring to future time. Traditionally, the Simple Future has both modal and temporal interpretations. In terms of future temporal interpretation, sentences with predicate in Future Simple refer to a time later than some other time contextually specified, denote an action with reference to future time or future intention: 
Your dentist will design a treatment plan in which hel she will recommend that you undergo specific dental procedures. You will be presented with the optimum treatment for your particular dental needs [41]. During the procedure, my gums will be opened to permit better access to the roots and jaw bone. Inflamed and infected gum tissue will be removed and the root surfaces will be thoroughly cleaned [36]. The above examples demonstrate the authors of the ICTs attempt to clarify key procedural moments.

In the case of the conditional tense in the studied texts, the Future Simple also refers to a time later than some other time contextually specified, or denotes a probability or hypothetical situation: In a worst case scenario, if a fracture occurs or is found, the tooth may need to be extracted [42]. If this is the case, I realize that there will be a fee for the time spent attempting the root canal [37]. If during the surgery the dentist finds a very deep cavity, fracture or any other finding that would compromise my tooth (teeth), the crown lengthening procedure will be stopped and the tooth would be extracted at or after the time of surgery [31].

Using the Future Simple (will form) can show that the addressor is considering different possibilities, for example, when regarding potential risks and possible complications: These are forces placed on teeth so they will move into their proper positions [45]. In most cases the root shortening will not cause problems. I understand that I can choose to do nothing and my present complaints will continue and may worsen [31].

In term of modality, will form and, rarely, shall form are used to create promise (a contractual obligation) [7, p. 165]: I will take reasonable steps to limit any complications of the treatment I have recommended [44]. I will contact the office immediately if symptoms persist or worsen. I will not, nor shall anyone on my behalf seek legal, equitable or monetary damages or remedies for such disclosure [37]. I also understand that upon completion of root canal therapy in this office, I shall return for a permanent restoration of the tooth involved [32].

The examples given underline not only doctors' careful behaviour, when fulfilling their professional duty, but the patient's involvement and accepting responsibility for the consequences of the health decision as well.

The Present Progressive verbs found in the ICTs make up only a minor share compared to the verbs in the Simple Present or Present Perfect. Our findings seem to agree with those by L. Goossens, who argues that the progressive aspect is infrequent com- pared with nonporgressive" [15, p. 165]. In the ICT, the Present Progressive verbs are mostly employed to describe and emphasize a continuing series of repeated actions, when actions need not to be completed, for example: I have told the dentist and/or his/her staff about any pertinent medical conditions I have, allergies (especially to medications) or medications I am taking, including over the counter medications such as aspirin [37]. Please consult with your physician before relying on oral birth control medication if your dentist prescribes, or if you are taking antibiotics [39].

Present Progressive verbs in the studied texts can also be used to denote an incomplete action, which has duration and has not yet come to an end, but its accomplishment follows: I am recommending the following treatment(s) for you: $<\ldots>$ [35]. I am freely giving my consent to allow and authorize Dr.

and/or his/her associates to render any treatment necessary or advisable for my dental conditions [40]. The low percentage of progressive aspect used as an indicator of ongoing processes can be explained by the peculiarities of temporal context of the reference situation of health decision making, which is based on resulativeness of past actions and mainly oriented towards the future.

The occurrence of Simple Past form of verbs in the ICTs can be described as negligible, since the context of the situation of informed consent giving / obtaining is future-oriented process, when the doctor provides the information regarding the treatment, possible alternatives, discloses associated risks and benefits, which refer to the future. In the studied texts, the Simple Past verbs represent an action or state as having occurred or having existed at a past moment or during a past period of time that is definitely separated from the actual moment of speaking: The United States Food and Drug Association, along with the manufacturer of one of these drugs (Fosamax) issued a warning to health care professionals on this issue on September 24th, 2004 [41]. I consent to the administration of anesthesia, $<\ldots>$, and to the use of such anesthetics as may be advisable with the exception of, to which I said I was allergic [35]. In the above examples the past tense refers to a single definite event in the past and may be accompanied by an overt indicator of time.

Limitations. As with any research, this study has certain limitations. It is limited to the investigation of verbs in terms of two semanticosyntactic categories of tense and aspect, while modals, imperatives, as well as category of voice were not included. Thus, thorough analysis of latter can contribute the clear 
picture of the dynamism of health decision making and mechanisms of its encoding.

Conclusion. As the situation of informed consent obtaining / giving can be described as mutually responsive collaborative dialogic conversation, thus, the language of informed consent templates has been found as more dynamic due to employing more verbs and verbal forms. And verbs in this context appear not only as equally meaningful elements in the sentences as nouns or nominative phrases, but as important constituents of the conceptual map for activities that occur over the reference situation. The dynamism of the documents studied is primarily predetermined by the multiplicity of aspects underlying the communicative situation of engaging patients in the discourse of decision making.

The results have revealed that the most frequently used grammar verb forms are Present Simple, Present Perfect, and Future Simple, while Present Progressive and Past Simple are marginal in the texts of informed consent templates for dental treatment. In order to achieve pragmatic goals and to avoid creating a minefield of difficulties for patients, the addressors tend to select verb forms, which convey the situation of information transfer and health decision making in the most precise way.

Tense and aspect considered as the most controversial syntactic and semantic categories play an important role not only in the structure of the sentence but interacting with each other act as temporal deictic markers, as indicators of the interpersonal function as they stresses the role of the addressor and addressee in communication, and as text-structuring devices.

The results of this study can contribute to creating the descriptive frameworks of the genre of informed consent for dental treatment as well as can be used in educational settings to assist medical students to comprehend and master this important grammatical area, and to improve their deep understanding of the interpretation and production of genre-specific texts.

\section{References:}

1. Костенко В. Г., Сологор І. М., Бєляєва О. М. Жанрові параметри англомовного документа інформованої згоди на виконання стоматологічного втручання. Наукові записки Національного університету «Острозька академія». 2019. Вип. 6(74). С. 69-73.

2. Поворознюк Р. В. Інформована згода як об'єкт перекладознавчих студій. Наукові записки Ніжинського державного університету ім. Миколи Гоголя. Філологічні науки. 2016. Кн. 2. С.67-75. URL: http: //nbuv.gov.ua/ UJNR/Nzfn_2016_2_15. (дата звернення: 12. 11. 2019).

3. Barro R., Lee J.-W. (2013). Educational Attainment Dataset. URL: http://www.barrolee.com (cited: 02. 12. 2019).

4. Bazerman C. Systems of genres and the enactment of social intentions. Genre and the New Rhetoric. London : Taylor and Francis. P. 79-101.

5. Biber D., Johansson S., Leech G., Conrad S. Longman Grammar of Spoken and Written English. Harlow : Pearson Education Limited, 1999. 1204 pp.

6. Brinton L. J. The Development of English Aspectual System. Cambridge : CUP. 1988. 1307 p.

7. Bryan A. Garner A. Dictionary of Modern Legal Usage (2d ed., Oxford U. Press. 1995. 953 p.

8. Bybee J. Perkins P., Pagliuca W. The evolution of grammar: Tense, aspect, and modality in the languages of the world. Chicago : University of Chicago Press. 398 p.

9. Comrie B. Aspect: An Introduction to the Study of Verbal Aspect and Related Problems (Cambridge Textbooks in Linguistics). Cambridge : Cambridge University Press. 1976. 142 p.

10. Comrie B. Tense (Cambridge Textbooks in Linguistics). Cambridge : Cambridge University Press. 1985. $139 \mathrm{p}$.

11. Crystal D. A Dictionary of Linguistics and Phonetics (4th Ed.). Oxford : Blackwell. 1996. 426 p.

12. Darriba P. English to Spanish translated medical forms: A descriptive genre-based corpus study. Translation and Interpreting 10(2): 2018. P. 122-141. DOI: 10.12807/ti.110202.2018.a09 (cited: 18. 03. 2020).

13. Depraetere I. On the resultative character of present perfect sentences. Journal of Pragmatics, Elsevier, 1998, 29 (5), P.597-613. https://halshs.archives-ouvertes.fr/halshs-00625754/document (cited: 14.03. 2020).

14. Gee J. P. An Introduction to Discourse Analysis: Theory and Method. Routledge, 1999. 176 p. URL: https://www.researchgate.net/publication/233896104_An_Introduction_to_Discourse_Analysis_Theory_and_ Method (cited: 17. 01.2020).

15. Goossens, Louis. The English progressive tenses and the layered representation of Functional Grammar. Tense and Aspects in Discourse. 1994. P. 161-178.

16. Grisot C. The Linguistic Expression of Temporal Reference. Cohesion, Coherence and Temporal Reference from an Experimental Corpus Pragmatics Perspective. Springer, Cham, 2018. P. 1-64.

17. Herwig A. Lexicon and Grammar. The ITB Journal. Vol. 6: Iss. 1. 2005. P. 53-63. doi:10.21427/D7NM9Q (cited: 2.02.2020). 
18. Hopper P. J. Aspect between Discourse and Gramma: An Introductory Essay for the Volume. Tense Aspect: between semantics and pragmatics. Amsterdam : John. Benjamins B.V., 1982. 350 p.

19. Hopper P. J. Discourse and the category Verb in English. Language and Communication. Special Issue: The Importance of Theory in Discourse Analysis. 1997. Vol. 17 (2). 1997. P. 93-102.

20. Leech G. The Pragmatics of Politeness. New York : Oxford University Press. 2014. 343 p.

21. Parodi G. University genres in disciplinary domains: social sciences and humanities and basic sciences and engineering. DELTA [online]. 2009, vol.25, n.2, pp.401-426. URL: https://doi.org/10.1590/ S0102-44502009000200007. (cited: 18.03.2020).

22. Pilegaard M. The ethics of informed consent. An applied linguistics perspective. Medical discourse in Professional, Academic and Popular settings. 2016. P. 79-102. DOI: 10.21832/9781783096268-006. (cited 14.04. 2020).

23. Reid K. I. Informed Consent in Dentistry. Journal of Law and Med Ethics. 2017. 45(1). P. 77-94. DOI: 10.1177/1073110517703102. (cited: 20.10. 2019).

24. Sager J., Dungworth D., McDonald, P. English Special Languages: Principles and practice in science and technology. Wiesbaden, Brandstetter. 1980.368 p.

25. Schneider K.P., Barron A. Pragmatics of Discourse. Walter de Gruyter GmbH \& Co KG, 2014. 640 p.

26. Tomlin R. Basic Word Order: Functional Principles. London : Croom Helm, 1986. 309 p.

27. Twaddell W. F. The English verb auxiliaries. Providence : Brown University Press. 1965. 42 p.

28. Van Dijk TA. News as Discourse. London : Routledge; 2013. 200 p. http://www.discourses.org/OldBooks/ Teun\%20A\%20van\%20Dijk\%20-\%20News\%20as\%20Discourse.pdf (cited: 20.03.2020).

29. Vučemilo L. Borovečki A. Readability and Content Assessment of Informed Consent Forms for Medical Procedures in Croatia. PLoS One. 2015. 10(9). URL: https://www.ncbi.nlm.nih.gov/pmc/articles/PMC4573755/ (cited: 25.01.2020).

30. Yazdannik A, Yousefy A, Mohammadi S. Discourse analysis: A useful methodology for health-care system researches. J Educ Health Promot. 2017; 6:111. 2017. doi:10.4103/jehp.jehp_124_15 (cited: 18.01.2020).

\section{Illustration sources:}

1. Consent for crown and bridge treatment. https://www.halfmoondental.com/pdf/crown $\% 20$ and $\% 20$ bridge $\% 20$ consent.pdf.

2. Consent Form for Endodontic Treatment: URL: https://www.padental.org/Images/OnlineDocs/ ResourcesPrograms/Practice\%20 Management/ConsentFormEndodontic.pdf.

3. Dental treatment consent form: URL: https://www.myclassicsmile.com/wp-content/uploads/2014/05/894 DENTAL_TREATMENT_CONSENT_FORM.pdf.

4. Informed consent and agreement for the invisalign patient. URL: https://www.novatofamilydental.com/ patient-forms/.

5. Informed Consent for Bone Grafting Procedure. URL: https://neworleansdentalcenter.com/consent-forms/ Consent for Bone Grafting Procedure.pdf.

6. Informed Consent for Crown Lengthening Surgery: http://www.denver-perio.com/Portals/11/ Documents/P\%20CONSENT\%20CROWN\%20LENGTHENING.pdf.

7. Informed consent form for endodontic treatment (root canal) URL: https://www.edic.com/wp-content/ uploads/2014/12/Endo.pdf.

8. Informed consent for dental procedure. URL: https://www.cda.org/MemberLogin/tabid/138/Default. aspx?returnurl.

9. Informed Consent for Endodontic Treatment. URL: https://www.endoexperience.com/filecabinet/ Consent $\% 20$ Forms $\% 20$ and $\% 20$ Printouts/Consent $\% 20$ Form $\% 20$ Examples/informed $\% 20$ consent $\% 20$ double $\% 20$ 04-20-02.pdf.

10. Informed consent for extractions. URL: https://novatofamilydental.com/wp-content/uploads/2019/09/ Novato-Family-Dental-Care-IC-extractions.pdf.

11. Informed Concent for General Dental Procedure. Abington Dental Associates. URL: https://www. abingtondental.com/wp-content/ uploads/2018/08/Informed-Consent-for-General-Dental-Procedures.pdf.

12. Restorative Treatment Consent Form. URL: http://www.fatemifamilydentistry.com/docs/Restorative\%20 consent.pdf.

13. Root canal treatment and informed consent URL: http:/theparkfamilydental.com/onlineforms/forms/ ROOTCANALTREATMENTANDINFORMEDCONSENT.pdf.

14. Patient Information/Informed Consent Form for Dental Treatment. URL: https://www.dentalclinicmanual. com > documents

15. Patient Consent to Begin Orthodontic Treatment. URL: https://www.tdicinsuranentsce.com/Portals/0/ Region-D/pdfs/forms/ Orthodontic-informed-consent.pdf. 


\section{КОстеНКО В. Г. ЧАС І АСПЕКТ У ФОРМАХ ПОІНФОРМОВАНОЇ ЗГОДИ НА СТОМАТОЛОГІЧНЕ ЛІКУВАННЯ У ФУНКЦІОНАЛЬНОМУ ВИМІРІ}

Добровільна поінформована згода пачієнта на медичне втручання є невіддільною частиною сучасної системи морального, етичного та правового регулювання надання медичної допомоги. Мета запропонованого дослідження - визначити, який час та аспект є найпоширенішими в англомовних текстахпоінформованоїзгодина стоматологічнелікування та проаналізувати чинники, що визначають їхню поширеність, з позицій функціональної лінгвістики. Вибір особових форм дієслів як предмета дослідження зумовлений їхньою складністю в семантичному, граматичному та синтаксичному планах. У досліджуваних текстах дієслова виступають такими ж значущими елементами у реченнях, як і іменники чи іменні словосполучення, вони є важливими складниками конщептуальної мапи діяльності, що відбувається упродовж референтної ситуачії. Динамізм документів поінформованої згоди відображається у високій насиченості дієсловами і зумовлений низкою чинників, що лежать в основі комунікативної ситуації залучення пацієнтів ухвалення рішення стосовно свого здоров'я. Широкий інформачійний потениіал дієслів полягає не лише у їхній здатності позначати дї̈, процеси, характерні у ситуачії обміну інформацією між лікарем та пацієнтом: дієслова також виражають повторність дій, повноту, безперервність, послідовність подій. Отримані результати продемонстрували, щзо найуживанішими граматичним формами дієслів є Present Simple, Present Perfect ma Future Simple, modi як Present Progressive ma Past Simple зустрічаються дуже рідко. Низький відсоток дієслів у Present Progressive ma Past Simple можна пояснити особливостями часового контексту референтної ситуаціі ухвалення рішення погодитися на стоматологічне лікування чи відхилити його, яка трунтується на результатах минулих дій, що є актуальними натепер, виражених Present Perfect, i переважно орієнтована на майбутнє. Для досягнення прагматичних цілей та для забезпечення максимально чіткої іоднозначної інформачії вибирають такі форми дієслів, які найточніме передають важливу інформацію та найлегше сприймаються пересічним паџієнтом. Дієслівний час та аспект відіграють важливу роль у структуруванні речення, виступають як часові дейктичні маркери, як індикатори міжсособистісної взаємодії, підкреслюючи роль адресанта та адресата, а також як засоби структурування тексту.

Ключові слова: усвідомлена поінформована згода на стоматологічне лікування, професійний дискурс, дієслово, час, аспект, частота. 